\title{
A Comparative Analysis of Fiscal Policy Changes in Selected European Union Countries outside the Eurozone ${ }^{1}$
}

\author{
Agata Szymańska \\ Institute of Economics, Faculty of Economics and Sociology \\ University of Lodz, Lodz, Poland \\ e-mail: agata.szymanska@uni.lodz.pl
}

\section{Abstract}

The aim of this article is to investigate the fiscal policy changes in six Central and Eastern European countries outside the Eurozone: Bulgaria, the Czech Republic, Croatia, Hungary, Poland and Romania. The analysis covers the period from 2004 to 2017. The study uses changes in the cyclically-adjusted primary balance as a main indicator to assess the fiscal policy stance. The results indicate that, in general, over the period from 2004 to 2017, the fiscal stance in these countries was somewhat contractionary.

Keywords: fiscal stance, cyclically-adjusted primary balance, non-Eurozone countries JEL: E62, H62

1 This work was supported by the Polish National Science Center under grant number DEC-2014/15/B/HS4/01996. 


\section{Introduction}

In recent years, public finance imbalances have been growing in many European Union countries. This was influenced by, inter alia, the consequences of the latest (started in 2008) economic and financial crisis, which seriously hampered GDP growth in the European Union Member States, as well as by numerous other conditions beyond the direct control of the governments. The peripheral Eurozone countries suffered seriously during this crisis and after it. The actions taken by the EU member states contributed to increasing the imbalance and, in some cases, determined the procyclical stance of fiscal policy after this economic crisis started. However, the latest data show that the condition of public finances in the EU has been improving. By the end of 2020, a sizeable improvement in public finances in comparison to 2009 is forecasted in the Eurozone (European Commission 2018).

Consistently basing fiscal policy on stabilisation objectives is important for fiscal authorities. Fiscal policy should be in a countercyclical position, that is, expansionary in bad times and contractionary during booms. The analysis of the changes in the cyclically-adjusted components of the budget balance (especially the cyclically-adjusted primary balance or the structural primary balance) is one of the simplified approaches used for fiscal position identification.

Central and Eastern European countries as members of the EU, although outside the Eurozone, are of particular special interest, mainly from the point of view of their future participation in the euro area. At present, the group of EU countries outside the Eurozone includes six economies from the Central and Eastern Europe region: the Czech Republic, Hungary and Poland (those three countries joined the EU in 2004), Bulgaria and Romania (accession to the EU in 2007), and Croatia (accession to the EU in 2013). The ability to conduct fiscal policy in a countercyclical manner is an important issue not only for countries participating in the single currency area, but also for each individual country.

The aim of this work is to assess the fiscal policy changes in six European Union countries outside the euro area. This article presents the evolution of the changes in fiscal policy, including analysis of the loosening or tightening of its restrictiveness. In this study, six countries are analysed: the Czech Republic, Hungary, Romania, Bulgaria, Poland and Croatia. The analysis covers the period from 2004 to 2017, which is the period between the most substantial enlargement of the EU (2004) and the year 2017 (2017 - the year with the latest available data). This study provides a comparative analysis of the fiscal policy stances during the pre-crisis and post-crisis periods. The investigation is based on, among others, the discretionary component of fiscal policy aggregates, that is, the component adjusted to the cycle. 


\section{Assessment of short-term fiscal stance}

According to Philip and Janssen (2002, p. 187), evaluations of short-term fiscal policy often use terms such as a "tight (or loose) fiscal stance" or "contractionary (or expansionary) fiscal policy".

The concept of fiscal stance aims “to capture governments' discretionary policy actions" (European Central Bank 2016). Discretionary fiscal policy is defined by the European Commission (2009) as a "change in the budget balance and in its components under the control of government." The definition determines the measure of that policy, which is the change in the balance after the exclusion of the budgetary impact of automatic stabilisers (see, for example, European Commission 2009).

There are two primary means of measuring fiscal policy stance: the change in the cyclically-adjusted primary balance and the bottom-up estimates of discretionary fiscal policy measures (European Central Bank 2016). The bottom-up estimates of discretionary policy measures are based on summing up all outcomes of policy measures included in the budget, which aims to classify the impact of individual expenditure and tax measures (Ibid. pp. 70-72).

Because the well-known definition of discretionary fiscal policy excludes the impact of the business cycle and many other fixed expenditures, especially in the form of interest paid on public debt, the standard approach used to analyse the fiscal stance is to investigate the changes in the cyclically-adjusted primary balance or the structural primary balance (European Commission 2016). The actual balance is not a good indicator because it contains the cyclical and structural impacts of many factors on the final (i.e., budget balance) outcome. The literature indicates the overall balance as a suitable indicator for the analysis of changes in fiscal policy; however, the measure needs to be judged with caution (Davis 1995). The alternative, and simple, measures of fiscal stance may be based on the analysis of changes in a current fiscal balance, changes in a primary balance, changes in a cyclically-adjusted or structural balance, changes in a domestic fiscal balance or changes in an operational balance (Davis 1995). However, as presented at the beginning of this section, nowadays, meaningful precedence is given to the cyclically-adjusted primary balance or the structural primary balance.

Fiscal stance may be regarded as either contractionary, expansionary or neutral, "depending on whether the government decides to decrease (contractionary), increase (expansionary) or leave discretionary expenditures unchanged (neutral)" (European Commission 2016). A fiscal stance of between -0.2 and 0.2 percentage points is often recognised as broadly neutral (Cimadomo 2005; European Central Bank 2018). In general, a negative change in the structural or cyclically-adjusted primary balance indicates an expansionary fiscal policy, whereas a positive change indicates a contractionary fiscal policy.

In the context of the Eurozone, there is a concept of the "euro area fiscal stance". The euro area fiscal stance is calculated as the sum of the fiscal stances of each Eurozone member state. Taking into account the approach to its calculation, Ademmer 
et al. (2016) argue that the aggregate fiscal stance is not a reasonable measure of fiscal stance for the euro area. They emphasise the relevance of fiscal sustainability and business cycle needs, which appear at national levels, especially owing to the heterogeneity of the business cycles among the Eurozone countries. Thus, it seems that the tightening fiscal policy in some countries and loosening in others may provide the conclusion about the neutral fiscal stance in the Eurozone as a whole. As a consequence, the aggregated outcome may not be optimal from the point of view of the individual member of the euro area.

Recent studies indicate that the (aggregate) euro area fiscal stance remained broadly unchanged before the global crisis (European Central Bank, 2018, among others). However, over 2008 to 2010, the fiscal policy in the euro area was expansionary, especially owing to the impact of several stimulus measures, including the European Economic Recovery Plan. After a period of severe recession, the Eurozone took action in order to provide debt consolidation, correct excessive deficits and maintain debt sustainability. The result of this was that in the years 2011-2013 the fiscal stance tightened, while in 2014 it was broadly neutral and even mildly expansionary in 2015 (Bańkowski and Ferdinandusse 2017, pp. 21-25).

\section{Fiscal policy in CEE countries - selected aspects in the context of fiscal stance}

The principal measure used in the analysis of fiscal stance is the cyclically-adjusted primary balance. In general, the cyclically-adjusted primary balance is calculated as an overall balance net of the cyclical component and interest payments, whereas the structural primary balance is understood as the actual budget balance net of the cyclical component, one-off and other temporary measures and interest payments. The total budget balance is not a good tool for discretionary stabilisation. It includes a set of elements that are not directly related to current policy conducted by fiscal authorities, like one-off or interest payments. These differences between actual (total) and structural balances, and other measures, are illustrated in Figure 1. It presents the composition of the total budget balance in the six CEE countries calculated for the year 2016.

In 2016, only in the Czech Republic were both the general government structural balance and the general government actual balance positive. However, values close to zero for both variables were observed in Bulgaria. In 2016, the remaining four countries had a deficit, both structural and actual. The biggest actual deficit was in Poland and Romania. Moreover, the composition of the budget balance indicates a negative value of the primary balance and the structural primary balance in these both countries. Figure 1 shows that in Hungary and Romania the primary balance was influenced by the negative one-off measure $(-0.1 \%$ of GDP in Hungary and $-0.4 \%$ of GDP in Romania), whereas in Croatia it was affected by a positive one-off correction $(0.1 \%$ of GDP). The contribution of the interest payments was 
the highest in Croatia and Hungary, suggesting the role of the "rigid" expenditures in influencing the budget balance. The statistical data show that Croatia and Romania experienced dynamics in debt development during the post-crisis period. Since 2005, the debt to GDP ratio in Hungary has exceeded the reference value established at the level of $60 \%$ of GDP. In the case of Croatia, the extension has been ongoing since 2011. The lowest share of general government debt in GDP was in Romania (between 2004 and 2008) and in Bulgaria (over the period 2009-2017), whereas the highest was in Hungary (2004-2012) and Croatia (2013-2017).

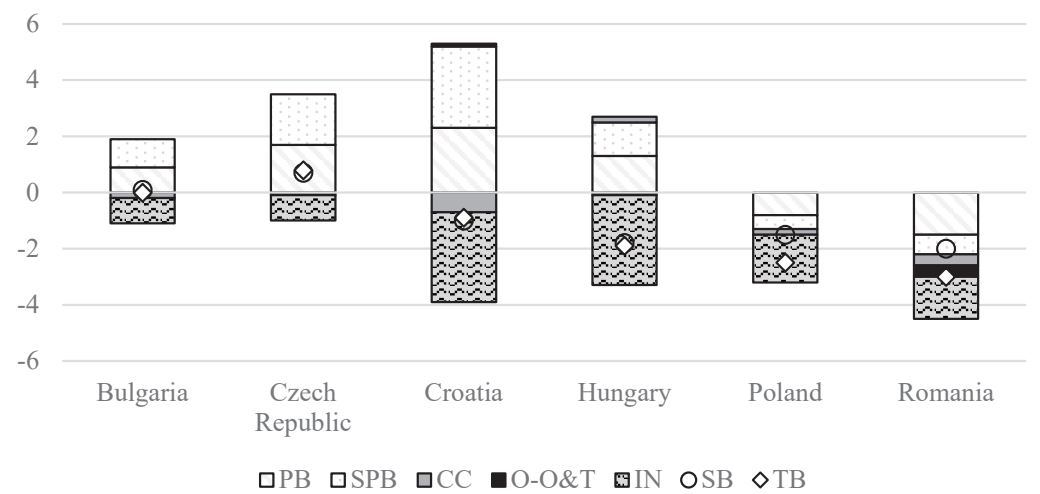

PB - primary balance, SPB - structural primary balance, CC - cyclical component, O-O\&T - one-off and other temporary measures, IN - interest payments, SB - structural balance, TB - total balance

Figure 1. Composition of general government budget balance in six CEE countries in 2016 Source: author's work and calculation based on European Commission (2018a).

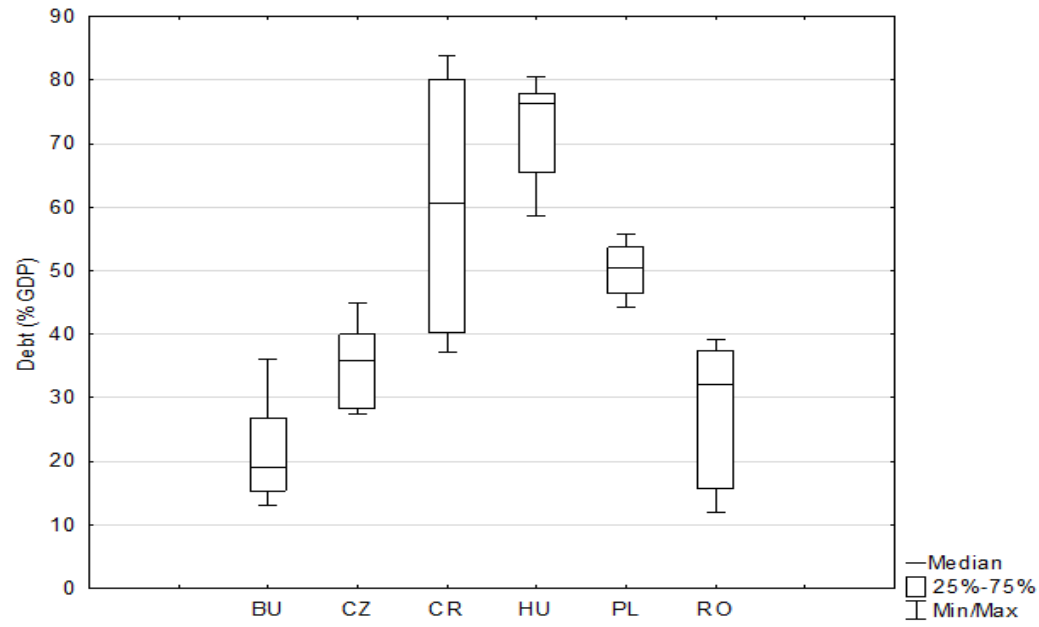

Figure 2. Boxplots of general government gross consolidated debt (\% of GDP) Source: author's work based on AMECO database. 
Figure 2 shows the asymmetry in debt development in the six CEE countries outside the Eurozone. Between 2007 and 2018, these countries experienced an increase in their debt as a share of GDP; however, as mentioned, over 2006 to 2010, Hungary had the highest debt to GDP ratio. The presented data show that Croatia had the highest dispersion of the variable for debt, whereas the lowest was in Poland. In four countries, the median value (as well as the maximum value) for the ratio of general government consolidated gross debt to GDP was below the Maastricht reference value (60\%) from 2004 to 2017.

The literature shows that sustainable public finance is an important issue for CEE countries. Some authors indicate that fiscal sustainability seems to be a problem in many CEE and other transition countries (e.g. Aristovnik and Berčič 2007). As a result, these countries need a set of structural reforms to improve their ability to generate structural surpluses (e.g. Uryszek 2015).

\section{Fiscal policy changes in six CEE countries}

This section provides an analysis of changes in the cyclically-adjusted primary balance. As mentioned previously, fiscal data comes from the AMECO database and covers yearly data from 2004 to 2017. In this study, the cyclically-adjusted primary balance is calculated as the difference between the total revenue of the general government adjusted for the cyclical component and the total expenditure, excluding interest, of the general government adjusted for the cyclical component (both adjustments based on potential GDP, under the definition of excessive deficit procedure). The output gap data is derived from the European Commission (2018b) and presents the calculation of the output gap as a $\%$ of potential GDP.

Figure 3 presents the changes in the calculated measure of the cyclically-adjusted primary balance (CAPB) for individual CEE countries. The analysis shows positive or negative differences, that is, an approximation of the restrictive (tightening) or expansive (loosening) fiscal policy stances, respectively.

When only the direction of changes in CAPB is taken into account, some conclusions about the restrictiveness of fiscal policy can be formulated. In Romania, significant episodes with a positive difference in calculated CAPB (i.e., periods with restrictive fiscal policy stance) were seen for 2005 and after 2009 till 2015. In the case of Bulgaria, a tightening in CAPB was observed in 2004, 2006, 2010-2013 and 2015-2017, whereas in Poland it was in 2010-2013 and 2015-2016, as well as in 2005 and 2007 (2007 with a small positive change). In Croatia, the positive fiscal policy stance was in 2005 and 2009, and since 2012, while in Hungary the positive episodes occurred in 2004 and 2007-2009, as well as in 2012. In the Czech Republic, positive changes in the calculated CAPB were observed in 2004, 2007, 2010-2011, 2013 and 2015-2017. Clearly, the fiscal stances of the individual countries did not cover the same periods. For example, in 2012, the change in CAPB was contractionary in five of the analysed CEE countries owing 
to the Czech Republic, where the change in the calculated CAPB was negative in that year. Before the crisis (i.e., before 2009), changes in CAPB in Bulgaria and Romania, in general, were negative. As presented in Figure 3, during the first phase of the crisis (2010-2011), of the six CEE countries, the change in CAPB was expansionary only in Croatia and Hungary, and it was contractionary in Bulgaria, the Czech Republic, Poland and Romania. Expansionary change in CAPB is observed after 2015 in Romania and Hungary.

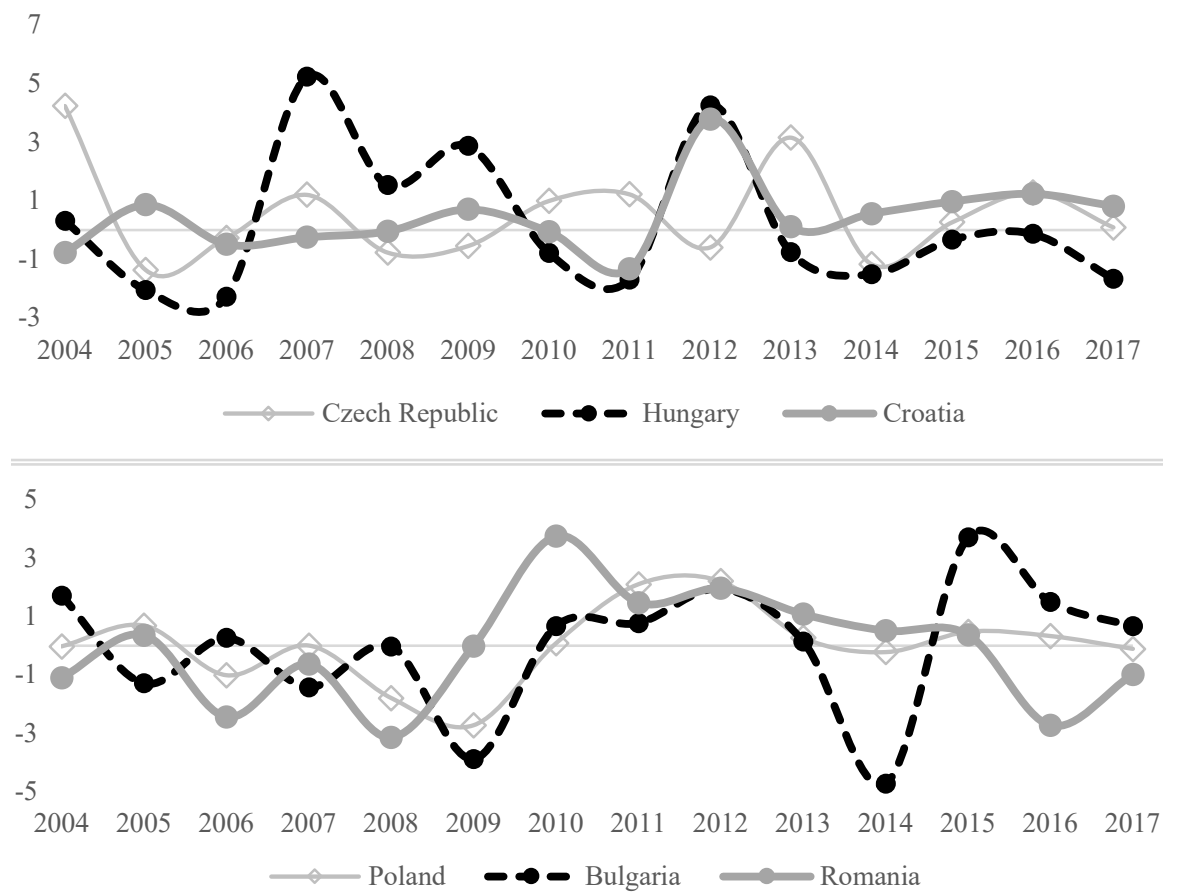

Figure 3. Fiscal policy stance (change in calculated CAPB) for individual CEE countries for 2004-2017 Source: author's calculations based on AMECO database.

The comparison of changes in CAPB and the output gap allows for a distinction between countercyclical and procyclical positions of fiscal policy. In general, fiscal policy stance is countercyclical when it is expansionary in bad times (countercyclical loosening), contractionary in good times (countercyclical tightening), whereas procyclical - when it is expansionary in good times (procyclical loosening), contractionary in bad times (procyclical tightening) (see e.g. IMF 2004, pp. 111-117). Taking into account the change in $\mathrm{CAPB}$, which ranged between -0.2 to 0.2 percentage points, it is possible to indicate the broadly neutral fiscal policy stance.

Figure 4 presents the output gap and changes in CAPB for two countries: Bulgaria and Croatia. In general, after the crisis, the fiscal policy in these two CEE countries was conducted in a tightening manner. The detailed analysis shows that in Bulgaria fiscal policy stance was generally contractionary, while in the years 2012-2013 and 2015- 
2016 it represented procyclical tightening. The output gap in the first stage of the global economic crisis (2009-2010) was negative; however, the change in the calculated CAPB in 2009 with respect to the preceding year represented expansionary fiscal stance, while in 2010 it was contractionary. A similar conclusion regarding the prevailing contractionary periods may be formulated towards Croatia - this country changed the path of fiscal policy changes from procyclical loosening $(2004,2006-2008)$ to procyclical tightening (2012-2016). The fiscal policy stance can be regarded as neutral in 2008 and 2013 in Bulgaria, whereas in Croatia - in 2008, 2010 and 2013 (i.e., the calculated change in CAPB was between -0.2 and 0.2 percentage points).
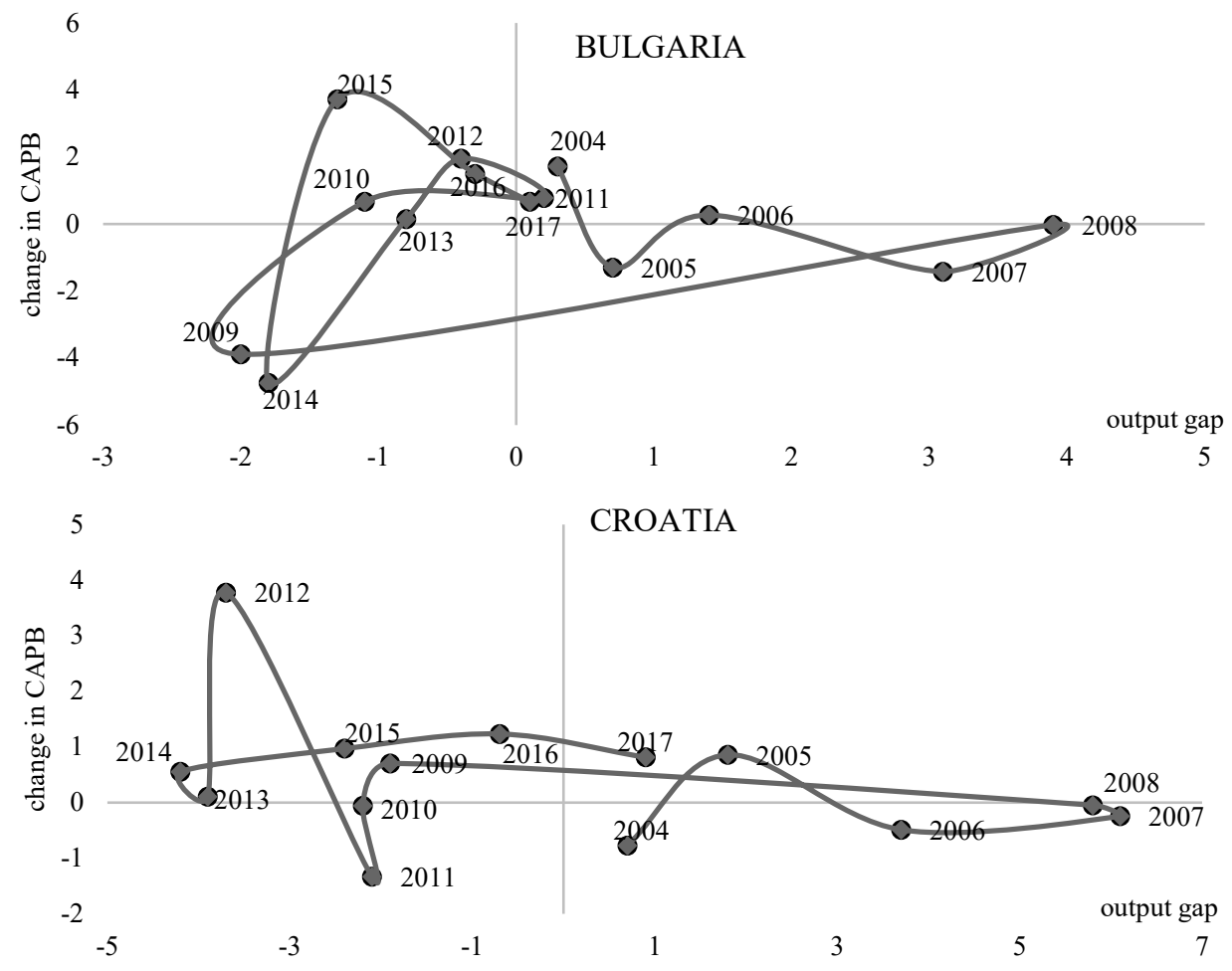

output gap as a \% of potential GDP

Figure 4. Changes in CAPB (in percentage points) and the output gap in Bulgaria and Croatia in 2004-2017

Source: author's work based on the AMECO database and European Commission (2018b).

In the case of the Czech Republic (the upper panel of Figure 5), it is difficult to make any conclusions about a clear direction of changes; however, the fiscal policy stance in that country, in general, was contractionary. In the year of the Czech Republic's accession to the EU (2004), the change in CAPB with respect to the preceding year shows contractionary fiscal stance (moreover, in 2004, the change in CAPB was the largest over the studied period of 2004-2017), and in the two following years the fiscal poli- 
cy stance exhibited procyclical loosening. In 2009-2016, the output gap was negative; however, the fiscal stance changed from loosening (2009) to tightening (in 2010-2011, 2013 and 2015-2016). In Hungary, fiscal policy stance was generally expansionary, opposite to the assessment of the stance in the other five countries. Taking into account the sample under analysis, it is possible to identify the following episodes: from procyclical loosening (2005-2006), through countercyclical tightening (2007-2008) and countercyclical loosening (2010-2011 and 2013-2014) to procyclical loosening (2015-2017).
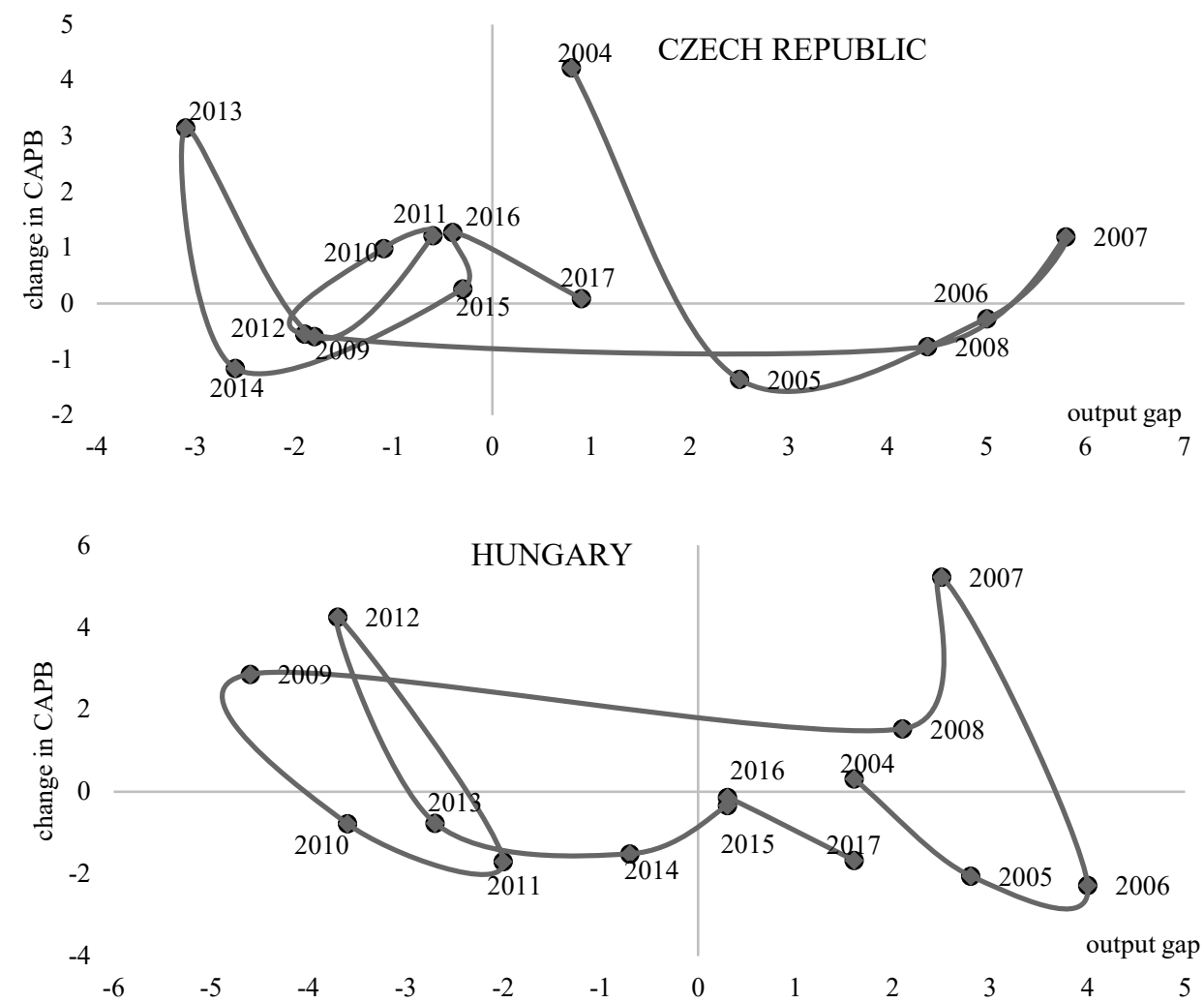

output gap as a \% of potential GDP

Figure 5. Changes in CAPB (in percentage points) and the output gap in the Czech Republic and Hungary in 2004-2017

Source: author's work based on the AMECO database and European Commission (2018b).

As presented in the upper panel of Figure 6, in Poland, the fiscal policy stance changed from neutral (2004) and procyclical tightening (2005) to procyclical tightening (2015-2016) and a broadly neutral fiscal stance in 2017. During the years 2010-2012 (the first phase of the global economic crisis), the changes in fiscal policy represented countercyclical tightening, whereas in 2013 and 2015-2016 they returned to procyclical tightening. Generally, the fiscal stance in Poland was contractionary. A broadly 
neutral fiscal stance was identified in 2004, 2007, 2010 and 2017. In Romania, the fiscal policy stance changed from procyclical loosening (2004 and 2006-2008) to procyclical tightening (2010-2015). Before the accession to the EU (i.e., before 2007) and before the global crisis, Romanian fiscal policy stance was mainly expansionary. The changes of CAPB in 2016 and 2017 with respect to the preceding years indicate the expansionary fiscal policy in Romania, similarly to at the beginning of the analysed sample. A broadly neutral fiscal stance was observed in 2009 (owing to the change in CAPB being equal to nearly -0.009 percentage points).
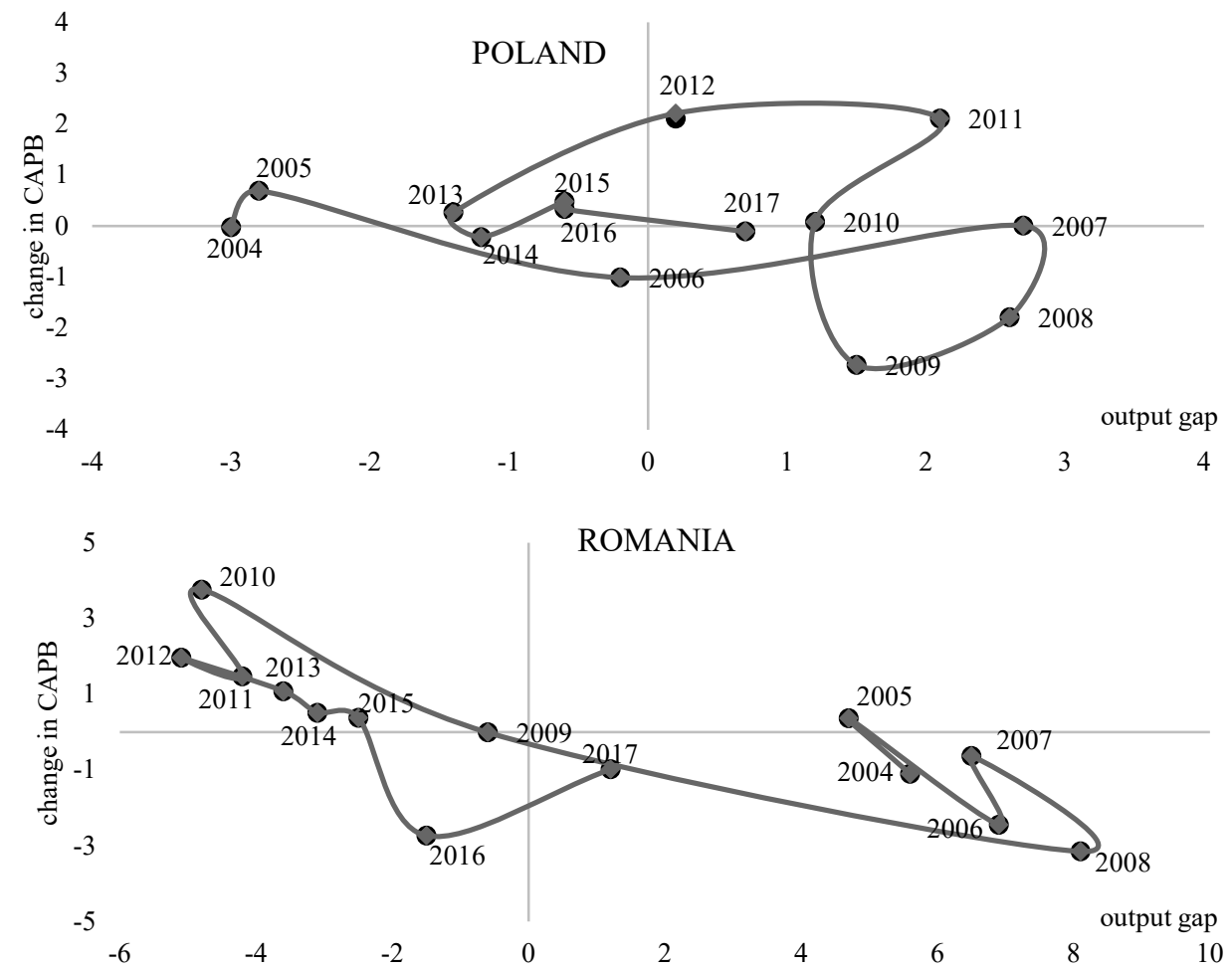

output gap as a \% of potential GDP

Figure 6. Changes in CAPB (in percentage points) and the output gap in Poland and Romania over 2004-2017

Source: author's work based on the AMECO database and European Commission (2018b).

The obtained results seem to be consistent with the literature. In general, the procyclicality of fiscal policy in the European transition countries, including CEE countries, is emphasised by, for example, Coricelli (2004); Atoyan et al., (2012) and Arsic et al. (2017). Moreover, the study by Arsic et al. (2017) indicates that fiscal policy in the CEE countries was procyclical in terms of the output gap, both in the pre- and post-crisis periods. A procyclical fiscal policy was recognised as typical for developing countries (Kaminski et al. 2004; Gavin, Perotti 1997; Alesina et al. 2008). In the case of devel- 
oped economies, many studies have investigated countercyclical fiscal policy (Gali and Perotti 2003), or a countercyclical stance in "bad times" and a slightly procyclical stance in "good times" (OECD 2002). The broadly neutral fiscal stance in the Eurozone has been highlighted by the European Central Bank (2018), among others.

A summary of the yearly fiscal stances for individual CEE countries is presented in Table 1. The data also includes results for the euro area as a whole.

Table 1. Fiscal policy stance in six CEE countries and the Eurozone

\begin{tabular}{|c|c|c|c|c|c|c|c|c|c|c|c|c|c|c|}
\hline & ষ্ণ & 옹 & ஃ̊ํ & 옹 & : & 유 & 을 & 궁 & 궁 & ํㅗㅇ & ণ্ণি & 율 & 을 & 홍 \\
\hline$B U$ & CR & $\mathrm{PE}$ & $C R$ & $\mathrm{PE}$ & $\mathrm{PE}$ & CE & PR & $C R$ & PR & PR & CE & PR & PR & $\mathrm{CR}$ \\
\hline CR & $\mathrm{PE}$ & $\mathrm{CR}$ & $\mathrm{PE}$ & $\mathrm{PE}$ & $\mathrm{PE}$ & PR & CE & CE & PR & PR & PR & PR & PR & $\mathrm{CR}$ \\
\hline CZ & CR & $\mathrm{PE}$ & $\mathrm{PE}$ & $C R$ & $\mathrm{PE}$ & CE & PR & PR & CE & PR & CE & PR & PR & $\mathrm{CR}$ \\
\hline $\mathrm{HU}$ & CR & $\mathrm{PE}$ & $\mathrm{PE}$ & $\mathrm{CR}$ & $C R$ & PR & CE & CE & PR & CE & CE & $\mathrm{PE}$ & $\mathrm{PE}$ & PE \\
\hline $\mathrm{PL}$ & CE & PR & CE & $\mathrm{CR}$ & $\mathrm{PE}$ & $\mathrm{PE}$ & $C R$ & $C R$ & $C R$ & PR & CE & PR & PR & PE \\
\hline RO & $\mathrm{PE}$ & $\mathrm{CR}$ & $\mathrm{PE}$ & $\mathrm{PE}$ & $\mathrm{PE}$ & CE & PR & PR & PR & PR & PR & PR & $\mathrm{CE}$ & $\mathrm{PE}$ \\
\hline EA & $\mathrm{PE}$ & $\mathrm{CR}$ & $\mathrm{CT}$ & $\mathrm{CT}$ & $\mathrm{PE}$ & CE & CE & PR & PR & PR & PR & CE & CE & $C F$ \\
\hline
\end{tabular}

PE - procyclical loosening, PR - procyclical tightening, CE - countercyclical loosening, CR- countercyclical tightening, shaded cells - broadly neutral fiscal stance

Source: author's work based on the AMECO database and European Commission (2018b).

As shown in the table, four episodes with broadly neutral fiscal policy stance (including three years with a countercyclical fiscal policy and one year with a procyclical stance) were observed in Poland, three episodes in Croatia and two in Bulgaria (in Bulgaria, both years were related to the procyclical position). Ignoring the broadly neutral positions, the fiscal policy stance was countercyclical in Hungary seven times and six times in Bulgaria. In 2008, almost all analysed countries conducted procyclical loosening (apart from Hungary, where fiscal policy stance was calculated as countercyclical tightening). A similar situation was observed in 2015, when all countries conducted procyclical policy, which in general was restrictive, with the exception of Hungary, where it was expansive. It is interesting to note that the fiscal policy stance in the Eurozone at the same time was, in general, broadly neutral. Procyclical tightening was applied in the years 2011-2014 as a consequence of the post-crisis consolidation processes introduced in the Eurozone.

\section{Conclusions}

This article presents issues related to the assessment of fiscal policy changes in selected Central and Eastern European countries, which are, in the near future, going to join the euro area. The analyses were primarily based on changes in the CAPB. The changes in that component of an overall balance are commonly used as the main measure 
to evaluate the fiscal position of a given country. The fiscal stance may be considered to be contractionary, expansionary or neutral depending on whether the change is positive, negative or stable, respectively. In most of the analysed countries, the calculated changes indicated the contractionary episodes of fiscal stance, with the exception of Hungary, while in the Eurozone the fiscal stance was rather broadly neutral (with the exception of the crisis period). In Hungary, periods of expansionary fiscal stance prevailed in the period studied in comparison to the other five CEE countries analysed.

Some limitations of this study should be mentioned. The analysis is based on changes in CAPB calculated on partial data derived from the AMECO database. A better assessment would be based on the structural primary balance, but the lack of comparable data for all six CEE countries over the period 2004-2017 influenced the decision to use the CAPB (calculated on the basis of available data). Moreover, the output gap (production function approach) data were derived from the database, rather than being calculated. As a consequence, those results may be slightly biased in the context of the procyclical or countercyclical assessments. Nonetheless, despite these shortcomings, the results obtained in this study are convergent with the results of other studies for transition economies.

\section{References}

Ademmer, E., Boeing-Reicher, C., Boysen-Hogrefe, J., Gern, K.J., Stolzenburg, U. (2016), Euro area fiscal stance: definition, implementation and democratic legitimacy, Directorate-General for the Internal Policies of the Union, European Parliament.

Alesina, A., Campante, F., Tabelini, G. (2008), Why is fiscal policy often procyclical. "Journal of the European Economic Association" 65, pp. 1006-1036.

Arsic, M., Nojkovic, A., Randjelovic, S. (2017), Determinants of discretionary fiscal policy in Central and Eastern Europe, "Economic Systems", 41 (3), pp. 367-378.

Atoyan, R., Jaeger, A., Smith, D. (2012), The pre-crisis capital flow surge to emerging Europe: Did countercyclical fiscal policy make a difference? IMF Working Paper No. 12/222. International Monetary Fund, Washington, D.C.

Bańkowski, K., Ferdinandusse, M. (2017), Euro area fiscal stance, EBC Occasional Paper Series, Paper No. 182, January 2017.

Cimadomo, J. (2005), Has the Stability and Growth Pact made fiscal policy more pro-cyclical?, La Lettre du CEPII, No. 247, July-August, Paris.

Coricelli, F. (2004), Fiscal policy in an enlarged EU. Revue de l'OFCE No. 91, 191-208.

Davis, J.M. (1995), Guidelines for fiscal adjustment, IMF, Pamphlet Series, No. 49, December.

European Central Bank (2016), The euro area fiscal stance, Economic Bulletin, Issue $4 / 2016$.

European Central Bank (2018), EBC Economic Bulletin, Issue 2/2018.

European Commission (2009), Public finances in EMU, European Economy 5/2009. 
European Commission (2016), Towards a positive euro area fiscal stance. Supporting public investments that increase economic growth, EPSC Strategic Notes, issue 20.

European Commission (2018), European economic forecast. Autumn 2018, Institutional Paper 089.

European Commission (2018a), Debt sustainability monitor 2017, Institutional Paper 071. January.

European Commission (2018b), Cyclical adjustment of budget balances. Autumn 2018. Directorate-General for Economic and Financial Affairs.

Gali, J., Perotti, R. (2003), Fiscal policy and monetary integration in Europe. Economic Policy 18 (37), pp. 533-572.

Gavin, M., Perotti, R. (1997), Fiscal policy in Latin America, [in:] Bernanke, B., Rotemberg, J. (eds.), NBER Macroeconomics Annual 1997. MIT Press, Cambridge, MA, pp. 11-72.

IMF (2004), World Economic Outlook. September 2004: The Global Demographic Transition, IMF.

Kaminski, G., Reinhart, C., Végh, C. (2004), When it rains, it pours: Procyclical capital flows and macroeconomic policies, [in:] Getler, M., Rogoff, K. (eds.), NBER Macroeconomics Annual 2004. MIT Press, Cambridge, MA.

OECD (2002), Fiscal stance over the cycle: The role of debt, Institutions and Budget Constraints. OECD Publishing, Paris.

Philip, R., Janssen, J. (2002), Developing an indicator for fiscal stance for New Zealand, [in:] The Impact of Fiscal Policy, book of proceedings of Workshops on Public Finance - Perugia, 21-23 Marzo 2002, Banca d'Italia, pp. 189-214.

Uryszek, T. (2015), Long-term sustainability of public finance in the Central and Eastern EU Member States, "Comparative Economic Research. Central and Eastern Europe”, 18 (4), pp. 47-61.

\section{Streszczenie}

\section{Analiza porównawcza zmian polityki fiskalnej w wybranych krajach Unii Europejskiej spoza strefy euro}

Celem artykułu jest analiza zmian polityki fiskalnej w sześciu krajach Europy Środkowo-Wschodnie spoza strefy euro: Bułgarii, Czechach, Chorwacji, Węgier, Polsce i Rumunii. Analiza obejmuje okres lat 2004-2017, czyli okres pomiędzy dotychczas największym rozszerzeniem Unii Europejskiej a najnowszymi dostępnymi danymi. W badaniu wykorzystano zmiany salda pierwotnego skorygowanego o wahania cykliczne, jako główny wskaźnik oceny kursu polityki fiskalnej. Wyniki wskazują, że polityka fiskalna w tych krajach była przeważnie restrykcyjna.

Słowa kluczowe: pozycja fiskalna, saldo pierwotne skorygowane o wahania cykliczne, kraje Unii Europejskiej spoza strefy euro 